\title{
Characteristic of selected genes controlling meat quality in pigs. A review*
}

\author{
B. Rejduch ${ }^{1,3}$, M. Różycki ${ }^{2}$ and A. Kozubska-Sobocińska ${ }^{1}$ \\ ${ }^{1}$ Department of Immuno- and Cytogenetics, \\ ${ }^{2}$ Department of Animal Breeding and Genetics, \\ National Research Institute of Animal Production \\ 32-083 Balice, Poland
}

(Received 29 March 2004; revised version 15 September 2004; accepted 31 January 2005)

\begin{abstract}
For many years, pig breeders have concentrated their pig improvement efforts on producing a population characterized by adequate meatiness. Development of molecular genetics techniques resulted in the detection of genes with major effects in quantitative traits. Segregation analysis of numerous microsatellite markers, evenly distributed throughout the genome, and variation of a productive trait in the reference family, may help to identify the chromosome region in which the major gene locus probably occurs. This analysis has led to the identification in pigs of over 2262 DNA microsatellite markers, and 1381 genes, amoung others FAT1, RYR1, RN, LEP, LEPR GH $I G F s, M y o D$ family genes presented in this articile which are significantly correlated to meat quality, carcass quality or growth rate.
\end{abstract}

KEY WORDS: pigs, genes, QTLs, meatiness, carcass quality

\section{INTRODUCTION}

Early breeding efforts at genetic improvement of pigs were based on selection for traits that could be determined on the basis of phenotype or reproductive value of animals. The main emphasis in pig improvement was placed on body muscling or fatness, and on the number of piglets per litter and sow. The next stage of breeding work was to search for traits responsible for animal performance.

Methods used until today were the basis of breeding work whose aim was to improve the genetic value of pigs. This work was carried out with large

\footnotetext{
* Supported by the State Committee for Scientific Research, Grant No. ZPO6D 02527

${ }^{3}$ Corresponding author: e-mail: brejduch@izoo.krakow.pl
} 
populations of animals. Genetic merit of animals was analysed by comparing their phenotypic traits with mean values of their contemporaries in individual herds (Różycki, 2001).

An important stage in pig breeding was the introduction of artificial insemination, which enabled better use of the genetic potential of herds or populations being improved. It also made possible the application of the BLUP (Best Linear Unbiased Prediction) - Animal Model program, which enables more accurate analysis of the genetic value of individual animals based on larger data sets that also account for traits of low heritability.

However, this type of genetic improvement of animals has reached a ceiling, making it necessary to supplement the analysis of pig breeding value with studies on molecular structure of genes whose expression is associated with the acquisition of specified levels of productive traits.

In the early 1990s in the European Union and Poland alike, special research projects (PiGMaP) were launched in order to gather as much information on the pig genome as possible (Archibald et al., 1991; Komisarek et al., 1998; Korwin-Kossakowska et al., 1998). The aim of these projects was also to make gene maps that pinpoint the structure (DNA nucleotide sequences) and, more importantly, the location of genes on specific chromosomes. Many genes and DNA sequences have been mapped and sequenced in pigs until today. The information obtained from brief summary of the Pig Genome Coordination Program for 2003 (http://www.genome.iastate.edu/newsletter/update2003.html) showed that in total, there were over 1381 genes and 2262 DNA markers in the database. The physical map is also growing quickly and there are now nearly 1315 genes and anonymous markers.

Molecular genetics techniques resulted in the detection of genes with major effects in quantitative traits (QTL). Segregation analysis of numerous microsatellite markers, evenly distributed throughout the genome, and variation of a productive trait in the reference family, may help to identify the chromosome region in which the major gene locus probably occurs. This analysis has led to the identification in pigs of many loci (such as $G H, R Y R I$ or $R N^{-}$) localized on different chromosomes, which are significantly correlated with meat quality, carcass quality, fatness or growth rate (Andersson et al., 1994; Wilkie et al., 1996; Miller et al., 2000).

\section{FAT1 GENE}

The first major gene of a quantitative trait (FATl) for fatness and growth in pigs was localized on chromosome 4 by using a wild boar intercross (Andersson et al., 1994). This gene region on chromosome 4 in the pig is homologous to parts 
of human chromosome 1 and 8 . The latest comparative mapping results between humans and pigs indicate that the QTL is located in a region homologous to HSA1q (q arm of human chromosome 1 pair) (Berg et al., 2002).

\section{RYANODINE RECEPTOR (RYRl) GENE}

The ryanodine receptor $(R Y R l)$ gene, responsible for pig sensitivity to stress, has received the most study. Pig sensitivity to stress is due to C-1843-T transition (resulting in the conversion of amino acid arginine into cysteine) in the RYRl gene. The product of a gene showing such mutation leads to calcium release unit in the endoplasmic reticulum of skeletal muscles. An analysis of meat quality made by MacLennen and Phillips (1992) showed that under intense stress conditions, a rapid glycogen disintegration leads to increase of lactic acid content in the muscle cells of the mutated gene carriers. In consequence the level of muscle acidification increases. At slaughter, such animals are a source of PSE (pale, soft, exudative) pork (Essen-Gustavsson et al., 1992). On the other hand, studies of pigs heterozygous for the RYRl genotype (Pedersen et al., 2001) demonstrated that they were characterized by $4-5 \%$ higher meat content and $14 \%$ lower fat content in carcass compared to mutation-free pigs. These studies indicate that the RYRl gene exerts an important influence on parameters of meat quality and carcass meatiness. For this reason, this gene is regarded as one with a major effect on these two traits. Analysis of the pig genome physical map made it possible to localize the $R Y R 1$ gene on chromosome pair 6 in the $\mathrm{q} 1.1 \rightarrow 1.2$ region.

\section{ACID MEAT (HAMPSHIRE) GENE ( $R N^{-}$RENDEMENT NAPOLE)}

Another gene controlling pig meat quality, regarded as a major effect gene, is the dominant acid meat (Hampshire) gene $\left(R N^{-}\right.$). Unfavourable $R N^{-}$gene increases the glycogen level as assessed by glycolytic potential and branching enzyme activity in the myofibres, giving rise to a lowered protein content, ultrastructural abnormalities and resulting in decreased technological abilities associated with high lactic acid levels postmortem (Monin and Sellier, 1985; Lebret et al., 1999).

The presence of a mutated allele in the genome causes meat processors even greater losses than PSE meat. The meat of pigs with $R N^{-/}$- genotype is also observed to contain less protein than the meat of animals without the mutated gene (Monin et al., 1992). Previous studies showed that the $R N$ gene is located between the markers SW120 and SW936 on the porcine chromosome 15 (Milan et al., 1995; Mariani et al., 1996; Reinsch et al., 1997). Further studies showed that the incidence of acid (Hampshire) meat is conditioned by a point mutation 
$(\mathrm{G} \rightarrow \mathrm{A})$ at codon 200 (changing arginine to glutamine) of the PRKAG3 gene. This gene was localized on chromosome pair 15 in the $\mathrm{q} 2.4 \rightarrow 2.5$ region, between microsatellite sequences S1006 and S1007 (Milan et al., 2000). It should be noted, however, that the $R N^{-}$gene has so far been identified only in European and American Hampshire pigs (Miller et al., 2000).

\section{OBESITY GENE (LEP) AND LEPTIN RECEPTOR (LEPR) GENE}

The obesity gene codes for protein named leptin ( $L E P)$ that is produced by adipocytes (fat-storage cells) and circulates in blood (Zhang et al., 1994). Its physiological function is still obscure, but it is thought that this hormone maintains stability of body fat mass (Friedman, 1997). The effect of leptin on feed intake has led to the hypothesis that leptin has a role in the feedback regulation of adipose mass on feed intake and energy output (Barash et al., 1996). Segantini do Nascimento Borges and Goulart (2002) showed that in pigs the obesity gene had a significant effect on shoulder weight and meat quality (texture). For this reason it represents a very interesting candidate gene for meat production.

Neuenschwander et al. (1996) were the first to report a partial cDNA sequence for pig leptin. Ramsay et al. (1998) presented the full length coding region of porcine $L E P$ gene. Next, Čepica et al. (1999) mapped the $L E P$ gene to SSC18q1.3 $\rightarrow 2.1$. In this gene several different polymorphisms (i.e. A2845T; T3996C; G2728A) were described (Stratil et al., 1997; Jiang and Gibson, 1999; Kennes et al., 2001) and evaluated for association with economically important traits in Yorkshire, Landrace and Duroc pigs (Kennes et al., 2001), as well as in Duroc, Hampshire, Landrace and Large White pigs (Jiang and Gibson, 1999). A significant difference was noticed in the frequency of $L E P$ alleles between the high- and low-fat groups of pigs. In the Large White pigs a significant effect was observed of the T/C polymorphism at nucleotide 3469 (T3469C) in the LEP gene on the percentage of backfat, lean in dissected shoulder as well as loin and ham (Jiang and Gibson, 1999) and on the mean daily weight gain in Landrace pigs (Kennes et al., 2001). Similar studies were carried out in Poland (Kurył et al., 2003) with pigs of the Pietrain, Zlotnicka Spotted and Landrace breeds and Torhyb and Stamboek lines. The authors also showed the T3469C polymorphism, identified with enzyme HinfI, which was detected in exon 2 of the $L E P$ gene and was shown to influence meat quality.

In the literature some data suggest that the leptin receptor (LEPR) gene (localized on chromosome pair 6 in the $\mathrm{q} 3.3 \rightarrow 3.5$ region) is correlated with backfat thickness and intermuscular fat content in pig carcasses (Ernst et al., 1997; Ovilo et al., 2002). However, the studies of Szydłowski et al. (2003) with Polish Landrace, Polish Large White and line 990 pigs demonstrated a haphazard nature of the correlation between polymorphism in exon IV of the LEPR gene and 
backfat thickness and loin eye area. The same authors suggested that the detected associations may be specific to some other breed of pigs.

\section{GROWTH HORMONE (GH) GENE}

The developing pig is particularly sensitive to treatment with growth hormone $(G H)$, which increases the average daily weight gain (Etherton et al., 1987), enhances protein accretion and reduces fat deposition (Campbell et al., 1989).

The growth hormone gene is localized on chromosome pair 12 (in the p1.4 region) (Larsen et al., 1995). In the 1990s several experiments were carried out to identify polymorphic variants of this gene and to determine the most favourable haplotype controlling carcass fatness (Schellander et al., 1994; Pierzchała et al., 1999). Slightly different nature were the studies of Kopchik and Cioffi (1991) showing that introduction of an exogenous growth hormone gene into pig organisms results, among others, in increased intensity of protein synthesis, which in turn makes it possible to increase weight gains by $10-20 \%$ while reducing fat in tissues by $30-40 \%$, and allows a $15-30 \%$ higher fattening efficiency compared to the control animals.

In the 1990s some experiments were carried out to study the influence of the bovine growth hormone gene $(b G H)$ transferred to the genome of the pig on growth and development of the animal (Solomon et al., 1994; Różycki et al., 1999). Gene transfer in animals is required to evaluate the potential for improving production efficiency, carcass quality and disease resistance of livestock. It is established that administration of exogenous porcine somatotropin ( $p S T)$ to pigs at different stages of growth and development results in alteration of body composition (Campbell et al., 1988; Smith and Kasson, 1990). The studies of Pursel and Rexroad (1993) showed that the bovine growth hormone gene (bGH) transferred to the genome of pig results in stimulation of muscular development. The transgenic pigs showed muscular hypertrophy at approximately 3 months of age, as well as longer hams. Furthermore, Solomon et al. (1994) showed that carcass tissue from $b G H$ - transgenic pigs reflected much more favourable levels of fatty acids as compared with control pigs.

\section{INSULIN-LIKE GROWTH FACTORS (IGFS) GENES}

In addition to its direct influence on tissue growth, the growth hormone acts indirectly through insulin-like growth factors (somatomedins) IGF1 and IGF2. These peptides are built of 70 and 67 amino acids, respectively, and synthesized by myoblasts during prenatal growth and postnatally in the muscle tissue (Montarras et al., 1996). 
The IGF1 gene in pigs was localized on chromosome pair 5 in the neighbourhood of the microsatellite sequence S0005 (Wintero et al., 1994). However, the study carried out by Lamberson et al. (1995) did not show that IGF1 concentration affected backfat thickness, area of the M. longissimus dorsi and percentage of lean. Biereder et al. (1999) reported a relationship between the $I G F 1$ level in blood and pig leanness.

Molecular genetics studies also led to the discovery of parental imprinting, whereby only genes transmitted by father (paternal imprinting) or mother (maternal imprinting) are expressed in the progeny. The very nature of imprinting makes it a highly valuable element of selection programmes, for it offers an efficient way of using differences between female and male lines.

The first gene detected in pigs to be characterized by expression in the form of parental imprinting, was the $I G F 2$ gene, localized on chromosome pair 2 in the p1.7 region, in the close neighbourhood of the microsatellite sequence SWC9. The IGF2 gene is expressed only within the line of boars, which makes possible restrictive selection for carcass lean (Nezer et al., 1999). Moreover, recent Swedish studies showed that $(\mathrm{G} \rightarrow \mathrm{A})$ transition in intron 3-G3072A of the gene (in conservative region of $\mathrm{CpG}$ islet) is related to an increase of about $10-20 \%$ in the muscle weight in pigs. This mutation was transmitted to the $\mathrm{F}_{1}$ generation (created for experimental purposes) by sires - homozygous or heterozygous carriers of the changed gene (Van Laere et al., 2003).

The human and mouse $I G F 2$ is expressed during embryo development, and its activity is regulated by maternal imprinting. This monoallelic expression is important for normal development of muscular tissue (Pedone et al., 1994). On the contrary, the corresponding receptor gene $I G F 2 R$ is paternally imprinted and expressed when transmitted by the mother.

The $I G F$ system consists also of six binding proteins (IGFBP-1 to -6$)$. The $I G F B P S$ can modify $I G F$ activity by binding $I G F s$ and preventing $I G F$ receptor activation. Up to now, the best known is the inhibiting influence of $I G F B P-2$, $I G F B P-3$ and $I G F B P-5$ expression on muscle differentiation in pigs (Green et al., 1994; James et al., 1996; Dunaiski et al., 1999).

\section{MYOD FAMILY GENES}

Based on a knowledge of molecular mechanisms controlling myogenesis (muscle development) several candidate genes may be selected as potentially affecting carcass meat content. In this regard the $M y o D$ family genes encoding muscle regulatory factors are adequate genes for carcass meat deposition. The $M y o D$ family consists of several structural and functional genes: myogenin - MYOG - located on 9q2.1 $\rightarrow 2.6$ of pig chromosome (Ernst et al., 1998), myogenic 
factor 3 - MYF3 (MYOD1) - located in the 2p1.4 $\rightarrow 1.7$ region (Čepica et al., 1999), myogenic factor 5 - MYF5 - located in the 5q2.5 region (Soumillion et al., 1997), and myogenic factor 6; herculin MYF6 (previously named MRF4) - located in $5 \mathrm{q} 2.4 \rightarrow 2.5$ between microsatellite DNA sequence SW378 and the most distal marker SW967 (Vykoukalova et al., 2003). The PCR-RFLP analysis showed the point mutations in MYOG in intron 2, MYF3 in intron 1 and exons 2 and 3 and MYF5 in intron 2. Application of the SNP-PCR technique (Single Nucleotide Polymorphism - Polymerase Chain Reaction) revealed the polymorphism of MYF6 gene in intron 1 and exons 2 and 3 (Knoll et al., 1997; Soumillion et al., 1997; Stratil and Čepica 1999; Te Pas et al., 1999; Vykoukalova et al., 2003).

The results of the studies performed on different breeds and lines (Cieślak et al., 2002; Kurył et al., 2002) lead us to suggest that the mutation in coding as well as non-coding regions of $M Y O G, M Y F 3$ and MYF5 genes is the mechanism changing the value of meat quality. For this reason it is very interesting to find out if the polymorphism in the regions of herculin (MYF6) is connected with carcass meat and fat deposition traits.

\section{CONCLUSIONS}

From the time when the first major genes controlling quantitative traits were discovered, researchers asked how to use molecular studies in pigs to advance genetic progress. Although the gene polymorphism studies explain only part of the genetic variation in pigs, knowledge of it may be used to analyse the genotype of individual animals. This is why information contained in quantitative trait genes should be definitely included in the evaluation of the productive value of farm animals.

\section{REFERENCES}

Andersson L., Haley Ch.S., Ellegren H., Knott A.S., Johansson M., Andersson K., Eklund-Andersson L.,Lilja-Edfors I., Fredholm M., Hansson I., Hakansson J., Lundström K., 1994. Genetic mapping of quantitative trait loci for growth and fatness in pigs. Science 263, 1771- 1774

Archibald A.L., Andersson L., Gustavsson I., Bosma A., Davis W., Fredholm M., Geldermann H., Gellin J., Groenen M., Ollivier L., Tucker E.M., Van de Weghe A., 1991. PiGMap - a European initiative to map the porcine genome. Anim. Genet. 22, 82-83

Barash I.A., Cheung C.C., Weigle D.S., Ren H., Kabigting E.B., Kuijper J.L., Clifton D.K., Steiner R.A., 1996. Leptin is a metabolic signal to the reproductive system. Endocrinology 137, 3144-3147

Berg F., Archibald A., Anderson S., Andersson L., Moller M., 2002. Comparative genome analysis between pig chromosome 4 and human chromosome 1 and 8 . Proceedings of $28^{\text {th }}$ International Conference on Animal Genetics. Gottingen (Germany), p. 157, Abstr. E057 
Biereder S., Wicke M., Von Lengerken G., Schneuder R., Kanitz W., 1999. Interaction between growth of skeletal muscle and $I G F-I$ in pigs of different sex. Proceedings of $50^{\text {th }}$ Annual Meeting of EAAP. Zurich (Switzerland), p. 162

Campbell R.G., Steele N., Caperna T.J., Mcmurty J.P., Solomon M.B., Mitchel A.D., 1988. Interrelationships between energy intake and endogenous porcine growth hormone administration on the performance, body composition and protein and energy metabolism of growing pigs weighing 25 to 55 kilograms live weight. J. Anim. Sci. 66, 1643-1655

Campbell R.G., Steele N.C., Caperna T. J., McMurtry J.P., Solomon M.B., Mitchell A.D., 1989. Interrelationships between sex and exogenous growth hormone administration on performance, body composition and protein and fat accretion of growing pigs. J. Anim. Sci. 67, 177-186

Čepica S., Yerle M., Stratil A., Schröffel J., Redl B., 1999. Regional localization of porcine MYOD1, MYF5, LEP, UCP3 and LCN1 genes. Anim. Genet. 30, 476-478

Cieślak D., Kurył J., Kapelański W., Pierzchała M., Grajewska S., Bocian M., 2002. A relationship between genotypes at $M Y O G, M Y F 3$ and muscle regulatory loci and carcass meat and fat deposition traits in pigs. Anim. Sci. Pap. Rep. 2, 77-92

Dunaiski V., Dunshea F.R., Walton P.E., Goddard C., 1999. Effect of growth hormone administration on IGF binding protein-3 mRNA levels in porcine tissues. J. Molecular Endocrinol. 22, 261-272

Ernst C.W., Kapke P.A., Yerle M., Rothschild M.F., 1997. The leptin receptor gene (LEPR) maps to porcine chromosome 6. Short communication. Mamm. Genome 8, 226

Ernst C.W., Mendez E.A., Robic A., Rothschild M.F., 1998. Myogenin (MYOG) physically maps to porcine chromosome 9q2.1-q2.6. Rapid communication. J. Anim. Sci. 76, 328

Essen-Gustavsson J.B., Karlström K., Lundström K., 1992. Muscle fibre characteristics and metabolic response at slaughter in pigs of different halothane genotypes and their relation to meat quality. Meat Sci. 31, 1-11

Etherton T.D., Wiggins J.P., Evock C.M., Chung C.M., Rebhun J.F., Walton P.E., Steele N.C., 1987. Stimulation of pig growth performance by porcine growth hormone: determination of the doseresponse relationship. J. Anim. Sci. 64, 433-443

Fiedman J.M., 1997. The alphabet of weight control. Nature 385, 119-120

Green B.N., Jones S.B., Streck R.D., Wood T.L., Rotwein P., Pintar J.E., 1994. Distinct expression of insulin-like growth factor binding proteins 2 and 5 during fetal and postnatal development. Endocrinology 134, 954-962

James P.L., Stewart C.E.H., Rotwein P., 1996. Insulin-like growth factor binding protein-5 modulates muscle differentiation through insulin-like growth factor-dependent mechanism. J. Cell Biol. 133, 683-693

Jiang Z.-H., Gibson J.P., 1999. Genetic polymorphisms in the leptin gene and their association with fatness in four pig breeds. Mamm. Genome 10, 191-193

Kawasaki E.S., 1990. Sample preparation from blood cells and other fluids. In: PCR Protocols: A Guide to Methods and Applications. Academic Press, New York, pp. 146-152

Kennes Y.M., Murphy B.D., Pothier F., Palin M.-F., 2001. Characterization of swine leptin (LEP) polymorphisms and their association with production traits. Anim. Genet. 32, 215-218

Knoll A., Nebola M., Dvorak J., Čepica S., 1997. Detection of a DdeI PCR/RFLP within intron 1 of the porcine MYOD1 (MYF3) locus. Anim. Genet. 28, 308-322

Komisarek J., Świtoński M., Pietrzak A., Klukowska J., 1998. The Polish “Pig Genome Mapping” project. IV. Segregation of chromosomal markers in generation $\mathrm{F}_{2}$. Anim. Sci. Pap. Rep. 16, $77-81$

Kopchick J.J., Cioffi J.A., 1991. Exogenous and endogenous effect of growth hormone in animals. Livest. Prod. Sci. 27, 61-72 
Korwin-Kossakowska A., Pierzchała M., Cymerowska-Prokopczyk I., 1998. The Polish "Pig Genome Mapping” project. X. Polymorphism of select microsatellite DNA sequences in the Zlotnicka Spotted and Polish Large White pigs and their $\mathrm{F}_{1}$ and $\mathrm{F}_{2}$ crosses. Anim. Sci. Pap. Rep. 17, 35-47

Kurył J., Kapelański W., Cieślak D., Pierzchała M., Grajewska S., Bocian M., 2002. Are polymorphism in non-coding regions of porcine $M y o D$ genes suitable for predicting meat and fat deposition in the carcass? Anim. Sci. Pap. Rep. 4, 245-254

Kurył J., Kapelański W., Pierzchała M., Bocian M., Grajewska S., 2003. A relationship between genotypes at the $G H$ and $L E P$ loci and carcass meat and fat deposition in pigs. Anim. Sci. Pap. Rep. 21, 15-26

Lamberson W.R., Safranski T.J., Bates R.O., Keisler D.H., Matteri R.L., 1995. Relationships of serum insulin-like growth factor I contrations to growth, composition, and reproductive traits of swine. J. Anim. Sci. 73, 3241-3245

Larsen N.J., Ellegren H., Brauner Nielsen P., Andersson L., 1995. Genetic variation at the growth hormone locus in a wild pig intercross; test association to phenotypic traits and linkage to the blood group D locus. Theor. Appl. Genet. 91, 1074-1077

Lebret B., Le Roy P., Monin G., Lefaucheur L., Caritez J.C., Talmant A., Elsen J.M., Sellier P., 1999. Influence of the three RN genotypes on chemical composition, enzyme activities, and myofiber characteristics of porcine skeletal muscle. J. Anim. Sci. 77, 1482-1489

MacLennan D.H., Phillips M.S., 1992. Malignant hyperthermia. Science 256, 789-794

Mariani P., Lundström K., Gustafsson U., Enfält A.-C., Juneja R.K., Andersson L., 1996. A major locus $(R N)$ affecting muscle glycogen content is located on pig chromosome 15. Mamm. Genome 7, 52-54

Milan D., Jeon J.-T., Looft C., Amager V., Robic A., Thelander M., Rogel-Gaillard C., Paul S., Iannuccelli N., Rask L., Rønne H., Lundström K., Reinsch N., Gellin J., Kalm E., Le Roy P., Chardon P., Andersson L., 2000. A mutation in PRKAG3 associated with excess glycogen content in pig skeletal muscle. Science 288, 1248-1251

Milan D., Le Roy P., Woloszyn N., Caritez J.C., Elsen J.M., Sellier P., Gellin J., 1995. The RN locus for meat quality maps to pig chromosome 15. Genet. Sel. Evol. 27, 1195-1196

Miller K.D., Ellis M., McKeith F.K., Bidner B.S., Meisinger D.J., 2000. Frequency of the Rendement Napole $R N^{-}$allele in a population of American Hampshire pigs. J. Anim. Sci. 78, 1811-1815

Monin G., Brard C., Vernin P., Naveau J., 1992. Effects of the $R N^{-}$gene on some traits of muscle and liver pigs. Proceedings of $38^{\text {th }}$ International Congress of Meat Science and Technology. Clermont-Ferrand (France), p. 78

Monin G., Sellier P., 1985. Pork of low technological quality with a normal rate of muscle $\mathrm{pH}$ fell in the immediate increase ate postmortem period: the case of the Hampshire breed. Meat Sci. 3, 49-63

Montarras D., Aurade F., Johnson T., Ilan J., Gros F., Pinset C., 1996. Autonomous differentiation in the mouse myogenic cell line, $\mathrm{C} 2$, involves a mutual positive control between insulin-like growth factor II and MyoD, operating as early as at myoblast stage. J. Cell Sci. 109, 551-560

Neuenschwander S., Rettenberger S.G., Meijerink E., Jorg H., Stranzinger G., 1996. Partial characterization of porcine obesity gene (OBS) and its localization to chromosome 18 by somatic cell hybrids. Anim. Genet. 27, 275-278

Nezer C., Moreau L., Brouwers B., Hanset R., Karim L., Kvasz A., Leroy P., Georges M., 1999. An imprinted QTL with major effect on muscle mass and fat deposition maps to the IGF2 locus in pigs. Nat. Genet. 21, 155-166

Ovilo C., Oliver A., Noguer J.L., Clop A., Barragan C., Varona L., Rodriguez C., Toro M., Sanchez A., Perez-Enciso L., Silio L., 2002. Test for positional candidate genes for body composition on pig chromosome 6. Genet. Sel. Evol. 34, 465-479 
Pedersen P.H., Oksbjerg N., Karlsson A.H., Busk H., Bendixen E., Henckel P., 2001. A within litter comparison of muscle fibre characteristics and growth of halothane carrier and halothane free crossbreed pigs. Livest. Prod. Sci. 73, 243-254

Pedone P.V., Tirabosco R., Cavazzana A.O., Ungaro P., Basso G., Luksch R., Carli M., Bruni C.B., Frunzio R., Riccio A., 1994. Mono- and bi-allelic expression of insulin-like growth factor II gene in human muscle tumors. Hum. Mol. Genet. 3, 1117-1121

Pierzchała M., Korwin-Kossakowska A., Zwierzchowski L., Łukaszewicz M., Zięba G., Kurył J., 1999. HaeII and MspI polymorphism of growth hormone gene in pigs and association with production traits. Czech J. Anim. Sci. 44, 441-445

Pursel V.G., Rexroad Jr. C.E., 1993. Status of research with trangenic farm animals. J. Anim. Sci. $71,10-19$

Ramsay T.G., Yan X., Morrison C., 1998. The obesity gene in swine: sequence and expression of porcine leptin. J. Anim. Sci. 76, 484-490

Reinsch N., Looft C., Rudat I., Kalm E., 1997. The RN-experiment: final porcine chromosome 15 mapping results. J. Anim. Breed. Genet. 114, 133-142

Różycki M., 2001. Methods for genetic modification of pigs (in Polish). Materials from the Symposium "Improvement of Animal Breeding Value Based on Selection for Genetic Markers and Transgenesis". Balice (Poland), pp. 3-15

Różycki M., Smoragg Z., Kopchick J.J., Chen Wen Y., Jura J., Pasieka J., Orzechowska B., Gajda B., Skrzyszowska M., 1999. Performance of transgenic pigs with the use of two different growth hormone gene constructs. J. Appl. Genet. 40, 29-37

Schellander K., Peli J., Kneissl F., Schmoll F., Mayr B., 1994. Variation of growth hormone gene in RYR 1 genotyped Austrian pig breeds. J. Anim. Breed. Genet. 111, 162-166

Segantini do Nascimento Borges G., Goulard L.R., 2002. Influence of obesity gene in quantitative traits of swine. Genet. Mol. Biol. 25, 29-35

Smith V.G., Kasson C.W., 1990. Growth performance and carcass characteristic of pigs administrated recombinant porcine somatotropin during 30 to 110 kilogram live weight. J. Anim. Sci. 68, 4109-4116

Solomon M.B., Pursel V.G., Paroczay E.W., Bolt D.J., 1994. Lipid composition of carcass tissue from transgenic pigs expressing a bovine growth hormone gene. J. Anim. Sci. 72, 1242-1246

Soumillion A., Rettenberger G., Vergouwe N.M., Erkens J.H.F., Lenstra J.A., Te Pas M.F.W., 1997. Assignment of the porcine loci for MYOD1 to chromosome 2 and MYF5 to chromosome 5. Anim. Genet. 28, 37-38

Stratil A., Čepica S., 1999. Three polymorphisms in the porcine myogenic factor 5 (MYF5) gene decteted by PCR-RFLP. Anim. Genet. 30, 79-80

Stratil A., Peelman L., Van Poucke M., Čepica S., 1997. A HinfI PCR-RFLP at the porcine leptin $($ LEP) gene. Anim. Genet. 28, 371-378

Szydłowski M., Maćkowski M., Szymoniak K., Nowak K., Maćkowiak P., Kaczmarek P., Kamyczek M., Eckert R., Różycki M., Świtoński M., 2003. A new polymorphism of the leptin receptor (T232A) in exon IV and its relationship with productive traits of pigs (in Polish). Materials from the 2nd Symposium of the Research Project PBZ-KBN/036/P06/2000, "Identification of Polymorphism of Genes in Domestic Animals and the Mechanism of their Effect on Productive Traits". Balice (Poland), pp. 46-47

Te Pas M.F.W., Harders F.L., Soumillion A., Born L., Buist W., Meuwissen T.H.E., 1999. Genetic variation at the porcine MYF-5 locus. Lack of association with meat production traits. Mamm. Genome 10, 123-127

Van Laere A.-S., Nguyen M., Braunschweig M., Nezer C., Collette C., Moreau L., Archibald A.L., Haley C.S., Buys N., Tally M., Andersson G., Georges M., Anderson L., 2003. A regulatory mutation in $I G F 2$ causes a major QTL effect on muscle growth in pig. Nature 425, 832-836 
Vykoukalova Z., Knoll A., Dvorak J., Rohrer G.A., Čepica S., 2003. Linkage and radiation hybrid mapping of the porcine MYF6 gene to chromosome 5. Anim. Genet. 34, 238-240

Wilkie P.J., Paszek A.A., Flinkenger G.H., Rohrer G.A., Alexander L.J., Beattle C.W., Schook L., 1996. Scan of 8 porcine chromosomes for growth, carcass and reproductive traits reveals two likely quantitative loci. Anim. Genet. 27, 117

Wintero A.K., Frdholm M., Andersson L., 1994. Assignment of the gene for porcine insulin-like growth factor I (IGFI) to chromosome 5 by linkage mapping. Anim. Genet. 25, 37-39

Zhang Y., Proenca R., Maffei M., Barone M., Leopold L., Friedman J.M., 1994. Positional cloning of the mouse obese gene and its human homologue. Nature 372, 425-432

\section{STRESZCZENIE}

\section{Charakterystyka wybranych genów warunkujących jakość mięsa świń}

Przez wiele lat prace prowadzone przez hodowców świń skoncentrowane były przede wszystkim na tworzeniu populacji charakteryzującej się odpowiednią mięsnością. Rozwój technik stosowanych w genetyce molekularnej zaowocował odkryciem genów, dających główny efekt w cechach ilościowych. Analiza segregacji licznych, równomiernie rozmieszczonych w genomie markerów mikrosatelitarnych, oraz zmienność określonej cechy produkcyjnej w rodzinie referencyjnej może prowadzić do wskazania regionu chromosomowego, w którym prawdopodobnie występuje locus genu głównego. Poprzez taką analizę oznaczono u świń około 2262 markery mikrosatelitarne oraz 1381 genów, pośród których geny $F A T 1, R Y R 1, R N, L E P, L E P R, G H, I G F S$ oraz geny należące do rodziny $M y o D$ wykazują istotne zależności z jakością mięsa, tuszy czy z tempem wzrostu. 
